Profit: Jurnal Kajian Ekonomi dan Perbankan 3 (1) 2019. P: 52-70

PROFIT : JURNAL KAJIAN EKONOMI DAN PERBANKAN

https://ejournal.unuja.ac.id/index.php/profit

E-ISSN : 2597-9434

\title{
TANTANGAN NELAYAN DALAM MENGHADAPI ERA GLOBALISASI EKONOMI PERSPEKTIF EKONOMI ISLAM \\ (Studi di Desa Sumberanyar Kec. Paiton Probolinggo)
}

\begin{abstract}
M Syaiful Suib \&
Halimatus

Sakdiyah*

* Universitas Nurul Jadid Paiton

\section{Abstract:}

Kemiskinan pada masyarakat nelayan di Desa Sumber Anyar dipahami sebagai ketidakmampuan dalam memenubi kebutuban bidup yang paling mendasar, seperti pemenuban kebutuban pangan. Kebutuban dasar yang lain, seperti kelayakan perumahan dan sandang dijadikan sebagai kebutuban sekunder. Kebutuban akan pangan merupakan prasyarat utama agar rumabtangga nelayan dapat bertahan bidup. Beberapa permasalahan dalam penelitian ini masalah yaitu: a. Faktor- faktor apa yang menyebabkan kemiskinan $b$. Bagaimana strategi rumabtangga nelayan dalam berusaha mengatasi factor-faktor penyebab kemiskinan tersebut.

Penelitian ini menggunakan metode penelitian kualitatif melalui pendekatan sosiologis, data dan informasi yang dibutubkan diperoleh melalui wawancara mendalam serta observasi. Dalam penelitian ini, menggunakan key informan yaitu: Kepala Desa, Kepala keluarga, dan seluruh jumlah anggota keluarga masyarakat miskin.

Hasil penelitian ini, pertama; Kemiskinan nelayan disebabkan oleh perubahan musim, sistem bagi hasil antara pemilik kapal dan nelayan yang kurang berimbang, perilaku masyarakat yang kurang memperbitungkan ekonomi. Kedua; Islam telah memberikan gambaran yang jelas terhadap perilaku ekonomi dalam berinteraksi dengan sesama melalui prinsip-prinsip syariah yang harus dilakukan oleh manusia, demi sustainable usahanya.
\end{abstract}

Keywords: Completenes Products, Products Quality and Image

Products and Consumer Loyality.

Email : 


\section{Pendahuluan}

\section{A. Latar Belakang}

Zona Ekonomi ekslusif merupakan area yang menjadi kesepakatan dunia terhadap eksistensi Negara dalam kekuasaan di pantai atau laut yang dimiliki Negara tersebut. Begitu juga Negara Indonesia yang wilayah lautnya hampir 2/3 dari luas daratan. Dari zona laut ini perariran Indonesia merupakan salah satu negara kepulauan terbesar di dunia setelah Amerika Serikat. Sumber kekayaan dan potensi kekayaan laut Indonesia terdiri dari beragam baik jenis ikan, terumbu karang, lumput laut dan sebagainya. ${ }^{1}$

Di dalam wilayah pesisir serta laut terkandung kekayaan beragam jenis sumber daya alam dimanfaatkan secara arif, potensi kekayaan tersebut dapat mendukung pembangunan sosial ekonomi menuju masyarakat Indonesia yang maju, makmur, dan berkeadilan dan sejahtera. ${ }^{2}$ Indonesia merupakan Negara bahari yang sangat luas dan perlu didukung oleh pemerintah dalam upaya memajukan di sektor kelautan. Dari data jumlah nelayan di Indonesia hampir mencapai 5-7 persen dari jumlah penduduk di Indonesia, dan berasal dari ekonomi menengah kebawah. Parameter ini diukur dari dari Indek Kesejahteraan Masyarakat pesisir. IKMP). ${ }^{3}$ salah satu penyebab dari menurunnya ekonomi masyarakat nelayan adalah perampasan laut (ocean grabbing) dan minimnya peralatan alat tangkap yang dimiliki nelayan. Seperti yang kita ketahu bahwa konsumsi ikan akan meningkatkan protein hewani bagi masyarakat, dan juga akan meningkatkan ekspor impor di sector kelautan apabila didukung oleh instrument/alat yang canggih dan ramah lingkungan.

Pada abad 21 ini telah terjadi proses globalisasi yang sangan significan terhadap kehidupan manusia terutama juga bagi nelayan. Ada beberapa dampak positif dan negative dari arus globalisasi tersebut diantaranya yang positif masyarakat mudah memperoleh barang konsumtif, membuka lapangan pekerjaan yang luas akan tetapi harus dibarengi dengan skill yang baik, pesatnya teknologi navigasi dan industry perkapalan semakin canggih, mendorong percepatan pertumbuhan ekonomi dan lain sebagainya. Ada juga dampak negative dari proses globalisasi diantaranya kompetitor usaha semakin banyak, pengangguran semakin banyak, skill dan kompetensi diperhitungkan dan lain sebagainya. ${ }^{4}$

Peran pemerintah terhadap sector laut mutlak diperlukan. Hal ini ketika disahkannya UU Kelautan pada tanggal 29 september 2014 ini menegaskan bahwa dengan disahkannya UU

\footnotetext{
${ }^{1}$ Ayu Puji Lestari, Hukum Laut Internasional Dan Pengaturannya Di Indonesia (Rafika Aditama, 2014). 2ibid

${ }^{3}$ Muhamad Karim dosen Agribisnis Universitas Trilogi, Direktur Pusat Kajian Pembangunan Kelautan dan Peradaban Maritim. https://news.detik.com/kolom/d-3977683/nelayan-butuh-kehadiran-negara).

${ }^{4}$ Puji Lestari.
}

52 Profit : Jurnal Kajian Ekonomi dan Perbankan 
Kelautan ini semakin ada penegasan bahwa Indonesia adalah Negara kepulauan berciri nusantra dan maritim. Tujuan pembangunan di daerah nelayan akan semakin mendapatkan wadah oleh pemerintah dan memberikan harapan baru bagi nelayan level menengah kebawah. Oleh karena itu laut harus dikelola secara professional dan sinergi antara pemerintah dan masyarakat nelayan dalam mendorong peningkatan potensi laut secara berkelanjutan. ${ }^{5}$

Islam sangat mengajarkan terhadap hubungan pemerintah dengan rakyat dalam berbagai bidang. Rakyat harus mengikuti aturan (UU) yang dibuat oleh pemerintah. Oleh kerana itu hubungan antara keduanya seharusnya berkelindan untuk mencapai tujuan bersama.

Kenyataan menunjukkan kehidupan nelayan dapat dikatakan bukan saja belum berkecukupan, melainkan juga masih terbelakang, termasuk dalam hal pendidikan, kesehatan, dan juga kesejahteraannya. Di beberapa sisi lain, kehidupan nelayan sudah ada yang mampu hidup berlebih, mereka yang menikmati status seperti itu pada umumnya tidak semata-mata mengandalkan hidupnya dari hasil kenelayanan, melainkan lebih berfungsi sebagai pedagang ikan pada level high class. Banyak juga nelayan yang bukan pedagang yang menyandang status ekonomi yang cukup lumayan, namun pada umumnya mereka bukan sekedar nelayan biasa, melainkan yang memiliki peralatan tangkap yang besar (bahkan eksploitatif), dengan hasil tangkapan yang tinggi. ${ }^{6}$

Lalu, bagaimana nasib nelayan tradisional yang hanya mampu menangkap ikan diperairan pantai, padahal jumlah nelayan yang demikian itu merupakan penduduk mayoritas dinegeri ini? Nampaknya sampai sekarang tingkat kesejahteraannya tidak semakin membaik, melainkan semakin lama justru cenderung semakin menurun, seiring dengan menurunnya tingkat hasil produksi hasil laut yang mereka peroleh. ${ }^{7}$

Kondisi ini ditambah dengan keterbelakangan pendidikan yang dialami oleh para nelayan pada umumnya, sehingga untuk mencari pendapatan alternatif diluar sektor kenelayanan, bukan hal yang mudah untuk mereka lakukan. Karena itu kondisi nelayan yang demikian itu perlu mendapat perhatian lebih, untuk menggalakkan pembangunan ekonomi dari hasil laut. Permasalahan lain yang paling urgen adalah untuk menghadapi globalisasi ekonomi yang simultan (cepat) menuntut masyarakat nelayan untuk lebih maju dalam berbagai hal seperti sarana, prasarana, pengeloaan hasil ikan, model penangkapan ikan, dan lain sebagainya. Pada tataran ini masyarakat nelayan masih sebatas pada pengelolaan yang masih tradisional dalam berproduksi. Era globalisasi merupakan

\footnotetext{
5 ibid

${ }^{6}$ Masyhuri, "Dimensi Ekonomi Kehidupan Sosial Masyarakat Nelayan”, Jurnal Ekonomi dan Pembangunan. 2001, Vol. IX. No. 1

7 Tommy Kurnia, Ironis, Indonesia Negara Maritim dan Tanab Subur Tapi Nelayan \& Petaninya Miskin, https://www.merdeka.com/uang/ironis-indonesia-negara-maritim-dan-tanah-subur-tapi-nelayanpetaninya-miskin.html
} 
proses kehidupan yang serba luas dan tidak terbatas dalam dunia, yang berpengaruh terhadap tatanan kehidupan bagi warga Negara dan bangsa di berbagai aspek bidang.

Ada beberapa arus globalisasi bagi nelayan dalam berkompetisi untuk mengambil peluang dan tantangan. Pertama; pasar bebas di mana kesempatan untuk mengekspor hasil produksi kelmancanegara semakin mudah dan tantangannya adalah produk yang dihasilkan harus berkualitas dengan harga yang kompetitif. Kedua ; kemajuan IPTEK, tantangan yang dihadapi terbesar adalah menciptakan pengangguran baru. Ketiga; asimilasi budaya tantangan yang dihadapi harus ada filter masuknya pengaruh budaya, apalagi di Indonesia yang menganut adat ketimuran. Keempat; investasi bisnis dan kerjasaama pada pemerintahan tantangan yang dihadapi adalah bisnis menjadi terbuka, investor banyak menanamkan sahamnya, maka diperlukan kompetnsi dan profesionalisme di bebagai bidang. Kelima menciptakan peluang kerja, tantangan yang dihadapi persaingan semakin ketat, inovasi dan kreasi yang harus matang dan mapan di segala bidang. ${ }^{8}$

Dari berbagai permasalahan di atas, maka yang menjadi persoalan pokok di manakah letak posisi nelayan sebagai bagian dari masyarakat Indonesia yang masih dalam taraf ekonomi menengah ke bawah serta peran berbagai pihak seperti pemerintah pusat dan daerah untuk meningkatkan dan mengoptimalkan peran mereka. Kedua; bagaimana menempatkan posisi nelayan pada era pasar bebas (globalisasi) ? Tujuan dari penelitian ini adalah 1) memberikan gambaran secara utuh tentang kondisi masyarakat nelayan. 2) strategi dan langkah-langkah yang harus dilakukan oleh masyarakat nelayan dalam menghadapi globalisasi ekonomi terutama pasar bebas. 3 Peran pemerintah dalam pengembangan masyarakat nelayan dan solusi apa saja terkait kondisi nelayan.

\section{B. Karakteristik Nelayan dan tipologi Nelayan}

Karakteristik masyarakat nelayan berbeda dengan karakteristik masyarakat petani karena perbedaan sumberdaya yang dimilki. Masyarakat petani (agraris) menghadapi sumberdaya yang terkontrol yakni lahan untuk memproduksi suatu jenis komoditas dengan hasil yang dapat dipridiksi. Dengan sifat yang demikian memungkinkannya lokasi produksi yang menetap, sehingga mobilitas usaha yang relatif rendah dan faktor resiko relatif kecil hal ini berbeda dengan nelayan yang dihadapkan kepada ketidakpastian local yang menjadi sumber penghasilannya. ${ }^{9}$

Nelayan adalah orang yang hidup dari mata pencaharian hasil laut, di Indonesia para nelayan biasanya bermukim di daerah pinggir atau pesisir laut, Komunitas nelayan adalah sekelompok orang yang bermata pencaharian hasil laut dan tinggal di desa desa atau pesisir, dengan

\footnotetext{
${ }^{8}$ Puji Lestari.

${ }^{9}$ Dkk Wahyono, Ary, Pemberdayaan Masyarakat Nelayan (Yogyakarta: Media Presindo, 2001).

54 Profit : Jurnal Kajian Ekonomi dan Perbankan
} 
menggunakan alat tangkap ikan dengan berbagai jenis dan model, biasanya menggunakan alat tangkap jarring, pancing, perahu, dan lain sebagainya. ${ }^{10}$

Didalam menjalankan fungsinya sebagai penangkap ikan, nelayan dibedakan menjadi 3 yaitu lapisan atas, menengah dan bawah. Lapisan atas adalah pemilik modal, lapisan menengah adalah orang yang dipercaya menukangi perahu dan menentukan hasil produksi oleh bos.Lapisan menengah mempunyai dua bagian dalam bagi hasil, sedangkan lapisan bawah adalah ABK yang menjual jasanya untuk bos ${ }^{11}$. Penentuan lapisan atau stratafikasi ini Menurut Soerjono Soekanto menyatakan bahwa stratifikasi social adalah pembedaan penduduk atau masyarakat ke dalam kelaskelas secara bertingkat ${ }^{12}$.

Dari stratafikasi tersebut kemudian muncul Tipologi nelayan yang digolongkan dengan beberapa criteria tertentu. Kriteria dalam tipologi ini dapat didasarkan pada tiga sudut pandang yaitu: ${ }^{13}$ Pertama ; Penguasaan terhadap alat tangkap yang dimiliki nelayan. Dalam hal ini, nelayan bisa dibedakan menjadi dua, yaitu nelayan yang memiliki alat sendiri dan yang tidak mempunyai alat tangkap sendiri yang disebut buruh nelayan. Kedua ; Investasi modal pada operasional penangkap ikan. Ketiga ; Berdasarkan teknologi peralatan tangkap ikan yang dimiliki.

Karakteristik nelayan buruh menurut Suhana (2011; 99) yaitu: ${ }^{14} 1$. Tidak memiliki factor produksi (kapal dan alat tangkap) dan mengoprasikan alat tanggap yang bukan miliknya. 2 . Bermodalkan tenaganya dalam proses penangkapan ikan. 3. Bekerja pada pemilik factor produksi (juragan/bos). 4. Berpendidikan rendah. 5. Minim dan tidak memiliki informasi akses pasar. 6. Terjebak pada lingkar kemiskinan dan bermukim di desa-desa miskin. 7. Memiliki ketergantungan ekonomi secara permanen terhadap pemilik modal.

Menurut Charles (2001), tipologi nelayan berdasarkan pada unsur ekologi (lingkungan). ${ }^{15}$ Ada empat, yaitu pertama ; Subsistence Fishers: nelayan yang menangkap ikan untuk kebutuhan konsumsi sehari-hari. Berdasarkan Unsur Ekologi (Lingkungan) tipologi nelayan masuk kategori Subsistence Fishers: nelayan yang menangkap ikan untuk kebutuhan konsumsi sehari-hari. Nelayan subsisten, melakukan penangkapan ikan hanya untuk mencukupi kebutuhan hidupnya sehari-hari, alat tangkap sederhana semisal sampan (kapal kecil) yang hanya muat 1-3 orang, jangkauan wilayah penangkapan terbatas biasanya hanya sekitar pantai.

\footnotetext{
${ }^{10}$ Wahyono, Ary.

${ }^{11}$ A. Satria, Pengantar Sosiologi Masyarakat Pesisir (Jakarta: Yayasan Pustaka Obor Indonesia, 2015).

12 J Mudiyatmoko, Sosiologi Dan Mengkaji Masyarakat (Bandung: Grafindo Media Pratama, 2007).

$13 \mathrm{~J}$ Mudiyatmoko.

14 Fitri Nurlita, Buchori Asyik, Irma Lusi Nugraheni, Analisis Pendapatan Rumah Tangga Nelayan Buruh Di Kelurahan Kangkung Tahun 2016, Jurnal FKIP Universitas Lampung, 17 Agustus 2017

${ }^{15}$ Satria.
}

55 Profit : Jurnal Kajian Ekonomi dan Perbankan 
Kedua; Native/ Indigeneous/ Aboroginal Fishers: kelompok nelayan yang mempunyai pola aktivitas nelayan tradisional dan seringkali hanya sebagai nelayan subsiten (pemenuhan kebutuhan sendiri). Nelayan di Sumberanyar tidak termasuk Commercial Fishers: [nelayan yang menangkap komoditas perikanan dalam memenuhi pasar domestic maupun ekspor, Tujuan melakukan penangkapan usaha ikan ini untuk perdagangan eksport].

Ketiga ; Recreational Fishers: nelayan yang melakukan aktivitas perikanan hanya sebagai rekreasi saja.

Keempat ; Commercial Fishers: nelayan yang menangkap komoditas perikanan dalam memenuhi pasar domestic maupun ekspor, yang tergolong menjadi dua kategori yaitu nelayan artisanal dan nelayan industry.

\section{Kondisi masyarakat Nelayan}

Staratafikasi sosial adalah penggolongan masyarakat pada kelas-kelas tertentu. Ada beberapa unsur pembentuk stratafikasi sosial pada masyarakat yaitu kekayaan, ilmu pengetahuan dan kekeuasaan. ${ }^{16}$ Menurut Pitirim Sorokin, stratafikasi social adalah perbedaan masyarakat pada lapisan kelas-kelas secara bertingkat. Robert M Z Lawang mengatakan staratafikasi social merupakan penggolongan masyarakat pada lapisan-lapisan hirarkis dengan dimensi kekuasaan, prestise dan privilese. Dari pengertian tersebut diperoleh pemahaman bahwa penggolongan masyarakat terbagi beberapa ketentuan-ketentuan yang menjadi indicator posisi masyarakat tersebut pada level-level tertentu. Salah satunya adalah kekayaan. Kekayaan merupakan poin terpenting bagi masyarakat dikatakan menempati posisi high class. Begitu juga sebaliknya, jika masyarakat/orang tersebut kategori miskin.

Kemiskinan didefinisikan " kurangnya kebutuhan primer maupun skunder untuk menjalani standar hidup yang layak". Pandangan lain berpendapat tidak tercukupinya kebutuhan dirinya dan keluarganya. Ketika orang tidak memiliki cukup uang untuk kelangsungan hidup, kebutuhan yang mendesak menjadi prioritas, tidak terpenuhi maka dikatakan miskin.. ${ }^{17}$

Menurut Teori Konservatif, kemiskinan tidak bermula dari struktur sosial, melainkan berasal dari karakteristik orang-orang miskin itu sendiri (misalnya malas, boros, tidak merencanakan kehidupannya, fatalis dan pasrah pada keadaan). Penduduk miskin mempunyai budaya miskin (culture of poverty). Penyebab orang menjadi miskin adalah karena ia terjebak materil, kelemahan jasmani, isolasi, kerentanan, dan tidak ketidakberdayaan. ${ }^{18}$.

\footnotetext{
${ }^{16}$ Satria.

${ }^{17}$ Michael Sharraden, Aset Untuk Orang Miskin : Perspektif Baru Usaha Pengentasan Kemiskinan (Jakarta: RajaGrafindo Persada, 2006).

${ }^{18}$ Sharraden.
}

56 Profit : Jurnal Kajian Ekonomi dan Perbankan 
Pada kehidupan nelayan kemiskinan dan tekanan- tekanan soaial-ekonomi yang dihadapi oleh rumah tangga nelayan berakar pada factor-faktor kompleks yang saling terkait. Factor-faktor tersebut dapat diklasifikasikan ke dalam factor alamiah dan non alamiah. ${ }^{19}$

Pertama; Faktor alamiah; factor ini berkaitan dengan fluktuasi musim-musim penangkapan.seperti perubahan musim, kehidupan nelayan sangat rentan terhadap musim, bukan hanya dari perubahan musim panen ke bukan musim panen, melainkan juga perubahan dari musim timur ke barat dan perubahan dari musim barat ke timur, sangat mempengaruhi pendapatan nelayan. Belum lagi jika dihadapkan pada musim paceklik. Oleh karena itulah dalam setiap perubahan musim tersebut kadang nelayan mengalami kesulitan keuangan, lebih- lebih pada musim paceklik.

Kedua ; Factor nonalamiah ; faktro ini berhubungan dengan keterbatasan daya jangkau teknologi penangkapan. Menurut Steinmetz (1905), perairan selat di Indonesia memiliki potensi sumber daya perikanan yang terbatas. (Drs. Kusnadi 2002). Oleh Karena itu di perlukan teknologi penangkapan yang paling canggih untuk menghasilkan tangkapan ikan yang besar.

Ketiga ; Sistem bagi hasil yang kurang menguntugkan. Sistem bagi hasil tangkapan ikan antara pemilik kapal dan nelayan yang kurang menguntugkan bagi nelayan buruh.

\section{STRATEGI UNTUK MENGHADAPI GLOBALISASI BAGI NELAYAN.}

Ada beberapa tawaran teori dan konsep yang perlu dilakukan oleh stakeholder bagi nelayan dalam menghadapi era Globalisasi, diantaranya ;

Pertama ; Konsep IPM ini membidik pada pembangunan manusia dan yang paling urgen adalah terpusat pada manusianya dan bukan hanya pada aspek ekonomi saja. Pembangunan manusia bukan hanya pada upaya meningkatkan kemampuan (kapabilitas) manusia, akan tetapi juga dalam upaya memanfaatkan kemampuan manusia tersebut secara maksimal. Pembangunan manusia didukung oleh empat pilar pokok, yaitu: produktifitas, pemerataan, kesinambungan, dan pemberdayaan. Fungsi secara umum dari IPM (Human Development Index/HDI ) dikaji meliputi pengukuran angka harapan hidup, tingkat pendidikan dan standart hidup suatu daerah sesuai dengan standarisasi kelayakan hidup secara umum yang ditetapkan pada suatu daerah. Dan nelayan merupakan bagian ini juga. Apabila IPM pada nelayan baik, maka akan membantu pembangunan nasional secara

\footnotetext{
${ }^{19}$ M. Kusnadi, Konflik Sosial Nelayan Kemiskinan Dan Perebutan Sumber Daya Perikanan (Yogyakarta: LKis Pelangi Aksara, 2002) <https://doi.org/10.22202/mamangan.1313>.

57 Profit : Jurnal Kajian Ekonomi dan Perbankan
} 
nasional, karena rata-rata masyarakat yang paling banyak penduduknya adalah daerah pesisir. ${ }^{20}$

Penjabaran empat pilar dari produktifitas, pemerataan, kesinambungan, dan pemberdayaan adalah sebagai berikut. Produktifitas nelayan dibentuk melalui kondisi masyarakat yang terbentuk dalam system social, yang terdiri dari nelayan tradisional, dan nelayan pemilik modal. Pola pemukiman nelayan yang kurang teratur mengikuti bentuk dari pantai disekitarnya. Produktifitas yang harus dilakukan oleh nelayan adalah meningkatkan hasil ikan, peremajaan alat tangkap, serta peningkatan kemampuan SDM bagi nelayan. Dari produktifitas ini kemudian diberdayakan dengan berbagai macam aspek dan daya dukung dari pemerintah semisal dengan di terbitkannya UU tentang kelautan, pemanfaatan hasil dari nelayan, adanya tempat pelelangan ikan, serta pelibatan nelayan terhadap pengembangan produksi hasil ikan dan juga akses informasi serta sosialiasasi.

Pemberdayaan masyarakat nelayan harus memperhatikan aspek natural, struktural dan kultural. secara natural masyarakat nelayan harus diberdayakan melalui perbaikan lingkungan, teknologi dan penataan lingkungan disekitarnya, sedangkan secara struktural masyarakat nelayan harus menggunakan peralatan modern, pembentukan kelompok dan hubungan kerja. Dan kultural dikehidupan nelayan diperbaiki melalui peningkatan pendidikan, menabung dan mengurangi gaya hidup yang konsumtif. ${ }^{21}$

Kedua ; beberapa teori-teori yang di kembangkan oleh beberapa pakar diantaranya, Chamber, Adam Smith dan lain sebaginya. Disisi lain, ada juga pembagian yang lebih spesifik terhadap beberapa kelas dalam ekonomi yang juga seharusnya menjadi perhatian bagi pemerintah sebagai regulator. Chamber membagi masyarakat, termasuk nelayan ke dalam ekonomi kelas bawah, menengah dan atas. Ekonomi kelas bawah ditandai dengan kebutuhan dan pemasukan yang tidak seimbang. Camber juga membagi dua terhadap kesenjangan masyarakat baik di daerah pesisir maupun derah perkotaan. Pertama kesenjangan antara perekonomian perkotaan (urban) yang dikenal dengan urban poverty dan pedesaan (rural poverty) merupakan salah faktor masyarakat dikatakan ekonomi kelas bawah. Penyebab keduanya adalah adanya urbanisasi atau perpindahan/migrasi penduduk dari desa menuju ke kota. ${ }^{22}$ Chamber membagi kemiskinan dengan 5 Indikator ; kemiskinan

\footnotetext{
${ }^{20}$ Mohammad Syaiful Suib, 'SINERGITAS PERAN PONDOK PESANTREN DALAM PENINGKATKAN INDEK PEMBANGUNAN MANUSIA (IPM) DI INDONESIA', Islam Nusantara, 1.2 (2017).

${ }^{21}$ Amrin Tahawila, 'Studi Akar Kemiskinan Nelayan Di Kelurahan Baiya Kecamatan Tawaeli Kota Palu', Katalogis, 2 (2014), 101-10.

22 ibid
}

58 Profit : Jurnal Kajian Ekonomi dan Perbankan 
(proper), ketidakberdayaan (powerless), Kerentanan menghadapi situasi (state of emergency), Ketergantungan (dependency), Keterasingan (isolation).

Penjelasan kelima unsur tersebut apabila ditarik kepada nelayan akan diperoleh gambaran sebagai berikut; nelayan dalam powerless menghadapi ancaman masuknya teknologi canggih dari Negara lain. State emergency ditunjukkan dengan adanya musim yang terus berputar mengikuti arus tata surya. Akibatnya, kemampuan untuk mencapai standar kesejahteraan menjadi rendah seperti: Ketersediaan pangan tidak sesuai atau tidak mencukupi standar gizi yang disyaratkan, Kesehatan relatif kurang terjamin, perumahan atau pemukiman yang kurang/tidak layak huni, Taraf pendidikan yang rendah dan lain sebagainya.

Disamping itu, peran pemerintah untuk mencapai kesejahteraan masyarakat nelayan diatas ada beberapa tingkatan untuk memenuhi kebutuhan bagi masyarakat nelayan. Teori yang dikemukan oleh Abraham Maslow ada lima yaitu 1. Kebutuhan Fisiologis, kebutuhan yang tidak terpisahkan pada diri setiap manusia. Kebutuhan ini bersifat homeostatik (usaha menjaga keseimbangan unsur-unsur fisik) seperti makan, minum, gula, garam, protein serta kebutuhan istirahat dan seks. Pada masyarakat nelayan yang menjadi kebutuhan ini adalah terpenuhinya kebutuhan rumah tangga nelayan atas kebutuhan pokok (primer) seperti sandang, papan dan pangan. 2] Kebutuhan akan keamanan (safety) stabilitas, proteksi, hukum, dan lain sebagainya. Seperti adanya jaminan asuransi nelayan, SNI pada kapal, alat tangkap ikan (pancing) dan lain sebagainya. 3] Kebutuhan Cinta (belonging dan love) dan Kebutuhan Self Esteem. seperti yang kita ketahu bersama bahwa nelayan terkadang hidup dilaut yang tanpa hari dan jam dengan durasi waktu yang tidak menentu. Pemerintah perlu membuat regulasi terkait dengan hak-hak dan kewajiban nelayan dengan pemilik kapal. Maslow berpendapat bahwa manusia dimotivasi untuk menjadi segala sesuatu yang dia mampu untuk menjadi itu. Walaupun kebutuhan lainnya terpenuhi, namun apabila kebutuhan aktualisasi diri tidak terpenuhi, tidak mengembangkan atau tidak mampu menggunakan kemampuan bawaannya secara penuh, maka seseorang akan mengalami kegelisahan, ketidaksenangan, atau frustasi begitu juga pada masyarakat nelayan. ${ }^{23}$

Disisi lain untuk meningkatkan kesejahteraan masyarakat nelayan, diperlukan campur tangan dari seperti pemerintah. Pemerintah sebagai pemegang regulasi (kebijakan) seharusnya berpihak pada masyarakat bawah. ${ }^{24}$ Terkait ini pemikiran Adam Smith ${ }^{25}$

\footnotetext{
${ }^{23}$ Siti Khasinah, 'Hakikat Manusia Menurut Pandangan Islam Dan Barat', Didaktika, 13.2 (2013), $296-317$. ${ }^{24}$ Pasal 33 UUD 1945
}

59 Profit : Jurnal Kajian Ekonomi dan Perbankan 
mendukung campur tangan pemerintah dalam menjaga stabilitas perekonomian yang seimbang. Salah satu penopang ekonomi Indonesia adalah pada sektor laut. Smith percaya bahwa skill dan kemampuan nelayan dalam produksi pada sektor laut akan meningkatkan output perkapita dengan memperluas pembagian kerja masyarakat nelayan. Smith menolak kekuatan monopoli oleh pemilik modal (Commercial Fishers) akan merusak kepada pasar. Meskipun disisi lain, sistem ekonomi yang mengadopsi pemikiran Smith ini disebut sebagai sistem liberalisme karena memberi kebebasan kepada individu dalam melakukan aktivitas ekonomi dan juga sistem kapitalisme, karena Smith menekankan pentingnya akumulasi modal untuk mencapai pertumbuhan ekonomi dan kesejahteraan. Perlunya akumulasi kapital dengan melakukan penghematan dan investasi modal sebagai kunci penting bagi pertumbuhan ekonomi. Investasi kapital merupakan cara terbaik untuk memperoleh keuntungan sebesar-besarnya dan menciptakan kemakmuran masyarakat nelayan.

Dari pemaparan diatas, peran nelayan pada sektor kelautan untuk menjaga kesetabilan ekonomi dapat juga dikolaborasikan dengan pemikiran Jean Baptiste Say dalam Hukum Say yang mengatakan bahwa penawaran menciptakan permintaannya sendiri, yang kemudian diterjemahkan oleh John Meynard Keynes tentang keterlibatan pemerintah untuk menstabilkan ekonomi di masyarakat. Rumus Hukum Say, bahwa penawaran barang (X) menciptakan permintaan untuk $(\mathrm{Y})$. teori say's memberikan kontribusi yang paling besar pada mazhab klasik. Teori ini mengatakan setiap penawaran akan menciptakan sendiri permintaannya' atau dikenal dengan “supply creates its own demand". Asumsinya, bahwa nilai produksi selalu sama dengan pendapatan. Dengan demikian, dalam keadaan seimbang, produksi cenderung menciptakan permintaannya sendiri. Ilustrasi Say jika dikaitkan dengan ekonomi nelayan mengatakan bahwa semakin besar tangkapan ikan dan variasi ikan (produksi) yang diperoleh, maka semakin besar jumlah pembelian yang dilakukan oleh pembeli (pasar), begitu juga sebaliknya. Teori ini berbanding lurus dengan melihat potensi dan peluang pada sector kalautan Indonesia. Posisi laut Indonesia yang sangat strategis masuk kepada wilayah segitiga pelayaran internasional, membuka peluang yang sangat potensial bagi pengembangan sektor laut meliputi ; transaksi bea cukai, impor, ekspor, produksi, konsumsi serta distribusi melewati jalur laut dan lain sebagainya. Pengembangan sektor laut akan membuka peluang bisnis yang besar bagi masyarakat di wilayah pesisir pantai. (nelayan).

\footnotetext{
${ }^{25}$ Hastarini Dwi Atmanti, 'Kajian Teori Pemikiran Ekonomi Mazhab Klasik Dan Relevansinya Pada Perekonomian Indonesia', 2.September (2017), 512.
}

60 Profit : Jurnal Kajian Ekonomi dan Perbankan 
Dari beberapa teori yang dipaparkan bahwa kesejahteraan masyarakat nelayan nampaknya kurang menguntungkan dan juga tidak semakin membaik sebaliknya malah semakin menurun, seiring dengan hasil tangkapan yang tidak menentu setiap waktu akibat perubahan musim. Akan tetapi di sisi lain untuk mencari pendapatan lain diluar sektor kenelayanan, maka perlu strategi-strategi yang dilakukan oleh masyarakat nelayan untuk mensejahterakan kehidupan para nelayan.

Ketiga : beberapa metode analsisis berkaitan dengan peran pemerintah terhadap masalah kesejahteraan masyarakat, terutama nelayan. Metode tersebut diantaranya sebagai berikut ; Pemerintah dapat menggunakan metode SWOT analisis dan Analisis AHP (Analytical Hierarchy Proccess). Untuk merespon kendala-kendala di lapangan.

SWOT analisis merupakan analisis yang digunakan untuk mengidentifikasi secara sistematis dalam merumuskan strategi. Fungsi secara umum analsis ini adalah untuk memaksimalkan kekuatan (strength) dan peluang (opportunities) namun secara bersamaan dapat meminimalkan kelemahan (weakness) dan ancaman (threats). ${ }^{26}$ Swot analisis jika di tarik pada masyarakat nelayan akan diperoleh gambaran sebagai berikut. Kekuatan (strength) dan Peluang (opportunities); indoensia terletak pada daerah maritim (daerah laut) dengan berbagai macam flora dan fauna laut yang beraneka ragam dengan berbagai macam berpotensi yang sangat besar bagi masyarakat nelayan. Potensi yang menjadi peluang bagi masyarakat nelayan ini juga akan membawa kepada perebutan wilayah pada sisi lain. ${ }^{27}$ Beberapa factor yang menjadi kelemahan (weakness) dan ancaman (threats) dapat dilihat dari SDM, Teknologi kelautan serta sarana prasarana meliputi TPI yang dimiliki oleh nelayan kita sangat minim dan sederhana.

AHP merupakan salah satu alat analisis dalam pengambilan keputusan yang baik dan fleksible. Pengambilan keputusan dalam AHP ini berdasarkan pada pengalaman dan penilaian dari pelaku/pengambil kebijakan yang diambil dengan menetapkan prioritas dan pertimbangan tertentu baik dari aspek kualitatif maupun kuantitatif. AHP didesain untuk menangkap persepsi orang yang berhubungan dengan permasalahan pada masyarakat nelayan melalui prosedur (aturan, kode etik) seperti adanya UU, PERPU, aturan kelautan, dan aturan lain yang mengikat, sehingga dapat dicapai skala prefensi dan berbagai alternatif pilihan yang baik bagi semua pihak. Oleh karena itu AHP rancangannya bersifat holistic,

\footnotetext{
${ }^{26}$ Rangkuti, Freddy. (2000), Teknik Membuat Perancangan Bisnis dan Analisis Kasus, Jakarta, PT Gramedia Pustaka.

27 Beberapa kasus terjadi pengkaplingan pada daerah laut, bahkan juga adanya pengusikan wilayah oleh beberapa Negara lain seperti Filipina, Cina dan lain sebagainya.
}

61 Profit : Jurnal Kajian Ekonomi dan Perbankan 
penalaran logika, pertimbangan berdasar instuisi dan menggunakan data kuantitatif serta data kualitatif. ${ }^{28}$

Hasil dari analisis swoot dan AHP ini akan berdampak pada peningkatan ekonomi masyarakat nelayan, pertumbuhan ekonomi di sekitar masyarakat pesisir, distribusi, konsumsi dan produksi berjalan seimbang di wilayah pesisir, pengangguran, kemiskinan, ketidakmeratnya ekonomi akan dapat di tekan, penciptaan lapangan pekerjaan dan tenaga kerja di sector-sektor laut seperti buruh nelayan, tenaga angkut, tenaga kontrak, tenaga industry di pengolahan ikan dan lain sebagainya.

Keempat : Ada juga ada beberapa Strategi dan upaya yang dilakukan oleh nelayan di diantaranya 1] Optimalisasi Peranan Anggota Keluarga Nelayan, hal ini dimaksudkan untuk memenuhi kebutuhan hidup sehari- hari tentunya tidaklah mudah bagi rumah tangga nelayan dengan tidak menentunya hasil kerja laut yang mereka dapatkan, berbagai usaha yang perlu mereka lakukan untuk mengurangi beban keluarga dan juga melobatkan peran istri nelayan membantu bekerja seperti halnya, membuat ikan teri, membuat petis, membuka usaha toko atau warung makan.2] Diversifikasi Pekerjaan. Dalam menghadapi ketidakpastian penghasilan, para nelayan keluarga nelayan melakukan kombinasi pekerjaan untuk mengurangi beban hidup dan membantu rumah tangga nelayan bebas dari kemiskinan. Diversifikasi pekerjaan yang dapat dilakukan oleh nelayan yaitu diantaranya membuka toko, berdagang buah- buahan, bercocok tanam dan menjual solar, bahkan menjajakan dagangan mereka sampai keluar daerah. 3] Jaringan Sosial bertujuan untuk mencapai atau memperoleh akses terhadap sumberdaya yang tersedia di lingkungannya. 4] Migrasi (perpindahan) dari tidak musim ikan ke musim ikan dan bergabung dengan kelompok lain. Tujuan migrasi adalah untuk memperoleh penghasilan yang tinggi dan agar kebutuhan hidup keluarga terjamin. Faktor yang penyebab kemiskinannya yaitu: Rendahnya pendidikan dan Minimnya modal yang dia miliki.

Kelima: Permasalahan lain yang paling urgen adalah untuk menghadapi globalisasi ekonomi simultan yang menuntut masyarakat nelayan untuk lebih maju dalam berbagai hal seperti pengeloaan hasil ikan, model penangkapan ikan, dan lain sebagainya. Pada tataran ini masyarakat nelayan masih sebatas pada pengelolaan yang masih tradisional dalam berproduksi bagi produknya. Era globalisasi merupakan proses kehidupan yang serba luas dan tidak terbatas dalam dunia, yang berpengaruh terhadap tatanan kehidupan bagi warga Negara dan bangsa di berbagai aspek bidang. Ada beberapa arus globalisasi yang

\footnotetext{
${ }^{28}$ Rangkuti Freddy, Teknik Membuat Perancangan Bisnis Dan Analisis Kasus (Jakarta: Gramedia Pustaka, 2000). 62 Profit : Jurnal Kajian Ekonomi dan Perbankan
} 
menjadikan bagi manusia terutama bagi nelayan dapat mengambil peluang dan tantangan. Pertama pasar bebas di mana kesempatan untuk mengekspor hasil produksi kelmancanegara semakin mudah dan tantangannya adalah produk yang dihasilkan harus berkualitas dengan harga yang kompetitif, kedua ; kemajuan IPTEK, tantangan yang dihadapi terbesar adalah menciptakan pengangguran baru, ketiga; asimilasi budaya tantangan yang dihadapi harus ada filter masuknya pengaruh budaya, apalagi di Indonesia yang menganut adat ketimuran., keempat; investasi bisnis dan kerjasaama pada pemerintahan tantangan yang dihadapi adalah bisnis menjadi terbuka, investor banyak menanamkan sahamnya, maka diperlukan kompetisi dan profesionalisme di bebagai bidang. Kelima menciptakan peluang kerja, tantangan yang dihadapi persaingan semakin ketat, inovasi dan kreasi yang harus matang dan mapan di segala bidang.

\section{Hasil Penelitian.}

Masyarakat nelayan di Desa Sumber Anyar masih taraf Rumah Tangga dikategorikan midlle Class. Hal ini dipahami sebagai ketidakmampuan dalam memenuhi kebutuhan hidup yang paling mendasar, seperti pemenuhan kebutuhan pangan, papan dan sandang. Kebutuhan akan pangan merupakan prasyarat utama agar rumahtangga nelayan dapat bertahan hidup. Masyarakat midlle class di Sumberanyar salah satunya disebabkan oleh perubahan musim, sistem bagi hasil antara pemilik kapal dan nelayan yang kurang berimbang, perilaku masyarakat yang kurang memperhitungkan ekonomi.

Nasib nelayan tradisional yang hanya mampu menangkap ikan diperairan pantai, dan adanya pebagian yang kurang merata hasil panen ikan. Begitu juga Kondisi pendidikan yang sebagian para nelayan di Desa Sumberanyar pada umumnya masih di bawah rata-rata, menyebabkan masyarakat kurang mampu untuk memenuhi kebutuhan primernya. Adanya tuntutan untuk mencari pendapatan alternatif diluar sektor kenelayanan, bukan hal yang mudah untuk mereka lakukan. Karena itu kondisi nelayan yang demikian itu perlu mendapat perhatian lebih, untuk menggalakkan pembangunan ekonomi dari hasil laut.

Nelayan di Sumber Anyar terbagi beberapa lapisan masyarakat yaitu lapisan atas, menengah dan bawah. Lapisan atas adalah pemilik modal, lapisan menengah adalah orang yang dipercaya menukangi perahu dan menentukan hasil produksi oleh bos.Lapisan menengah mempunyai dua bagian dalam bagi hasil, sedangkan lapisan bawah adalah ABK yang menjual jasanya untuk bos. Begitu juga Penguasaan terhadap alat tangkap yang dimiliki 
nelayan masih minim, meskipun ada beberapa yang sudah baik dan sesuai dengan standart alat tangkap.

Msyarakat nelayan Sumber Anyar masuk tipologi nelayan Subsistence Fishers: nelayan yang menangkap ikan untuk kebutuhan konsumsi sehari-hari dan sebagaian kecil Nelayan subsisten, melakukan penangkapan ikan hanya untuk mencukupi kebutuhan hidupnya sehari-hari, alat tangkap sederhana semisal sampan (kapal kecil) yang hanya muat 1-3 orang, jangkauan wilayah penangkapan terbatas biasanya hanya sekitar pantai. Ada juga sebagian Commercial Fishers: [nelayan yang menangkap komoditas perikanan dalam memenuhi pasar domestic tidak ekspor. Oleh karena itu diperlukan adanya upaya dari pemerintah untuk lebih meningkat pada export yang lebih luas.

Di sisi lain ada juga penyebab nelayan masih taraf midlle class adanya tekanantekanan soaial-ekonomi yang dihadapi oleh rumah tangga nelayan pada beberapa factorfaktor seperti factor alamiah dan non alamiah. Faktor alamiah disebabkan fluktuasi musimmusim penangkapan.( perubahan musim). Kedua ; Factor nonalamiah ; faktro ini berhubungan dengan keterbatasan daya jangkau teknologi penangkapan. Ketiga ; Sistem bagi hasil yang kurang menguntugkan. Sistem bagi hasil tangkapan ikan antara pemilik kapal dan nelayan yang kurang menguntugkan bagi nelayan buruh. Oleh karena itu melihat Kondisi sarana prasarana TPI di Sumberanyar seperti pengeloaan hasil ikan, model penangkapan ikan, dan lain sebagainya perlu ada pengembangan dan perhatian serius dari pemerintah. Meskipun di sisi lain sarana prasarana di daerah nelayan TPI cukup menggembirkan. Konsep yang ditawarkan diatas sangat perlu dilakukan untuk menunjang sustainability profesi nelayan dalam memenuhi kebutuhan ekonomi mereka sendiri.

Strategi yang sangat perlu dilakukan Pemerintah dengan konsep IPM an konsepkonsep diatas yang membidik pada pembangunan manusia bukan saja pada aspek ekonomi saja. Akan tetapi upaya meningkatkan kemampuan (kapabilitas) manusia meliputi pengukuran angka harapan hidup, tingkat pendidikan dan standart hidup suatu daerah sesuai dengan standarisasi UMR dan hidup layak yang memenuhi standart nasional. Dengan adanya pendidikan yang tinggi, pengembangan alat tangkap dengan teknologi yang canggih, dapat mencegah ancaman SDM dan teknologi canggih dari negara lain. Sehingga pertumbuhan ekonomi secara nasional dapat tercapai dengan maksimal.

\section{Peran Nelayan Perspektif Islam.}


Islam mengatur segala bentuk interaksi manusia satu dengan lainya. Oleh kerana itu status yang melekat akan dirinya diatur oleh Allah swt. Sebagai manusia seharusnya memperhatikan halhal sebagai berikut;

Pertama ; Dalam islam kehidupan manusia terutama ia sebagai nelayan, erat hubungannya satu dengan yang lain. Hubungan manusia ketika berinteraksi dengan manusia lainnya disebut sebagai makluk sosial, maka seharusnya manusia memperlakukan manusia lainnya dengan baik dengan mengikuti ajaran, aturan, atau syariat yang telah digariskan oleh Allah. Firman Allah dalam surat al-Hujurat ayat 13, artinya ; ${ }^{29}$; Hai manusia, Sesunggubnya Kami menciptakan kamu dari seorang lakilaki dan seorang perempuan dan menjadikan kamu berbangsa - bangsa dan bersuku-suku supaya kamu saling kenal-mengenal. Sesunggubnya orang yang paling mulia diantara kamu disisi Allab ialah orang yang paling taqwa diantara kamu. Sesungguhnya Allah Maha mengetahui lagi Maha Mengenal.

Manusia ketika berhubungan dengan manusia lainnya, mengalami pasang surut dalam bertingkah, prilaku dan berinteraksi. Oleh karena itu Allah memberikan tuntunan berupa adanya dua sumber hukum syariat yaitu al-Qur'an dan al-Hadits. Salah satu isi dari tuntunan ini adalah tentang etika, bagaimana berperilaku dengan sesama harus sesuai dengan kedua tuntunan ini

Menurut Hendar, Konsep tauhid sebagai The Principle of Metaphysics, sekaligus The Principle of Sosio-Enomic Ethic V alues, digambarkan sebagai berikut : ${ }^{30}$

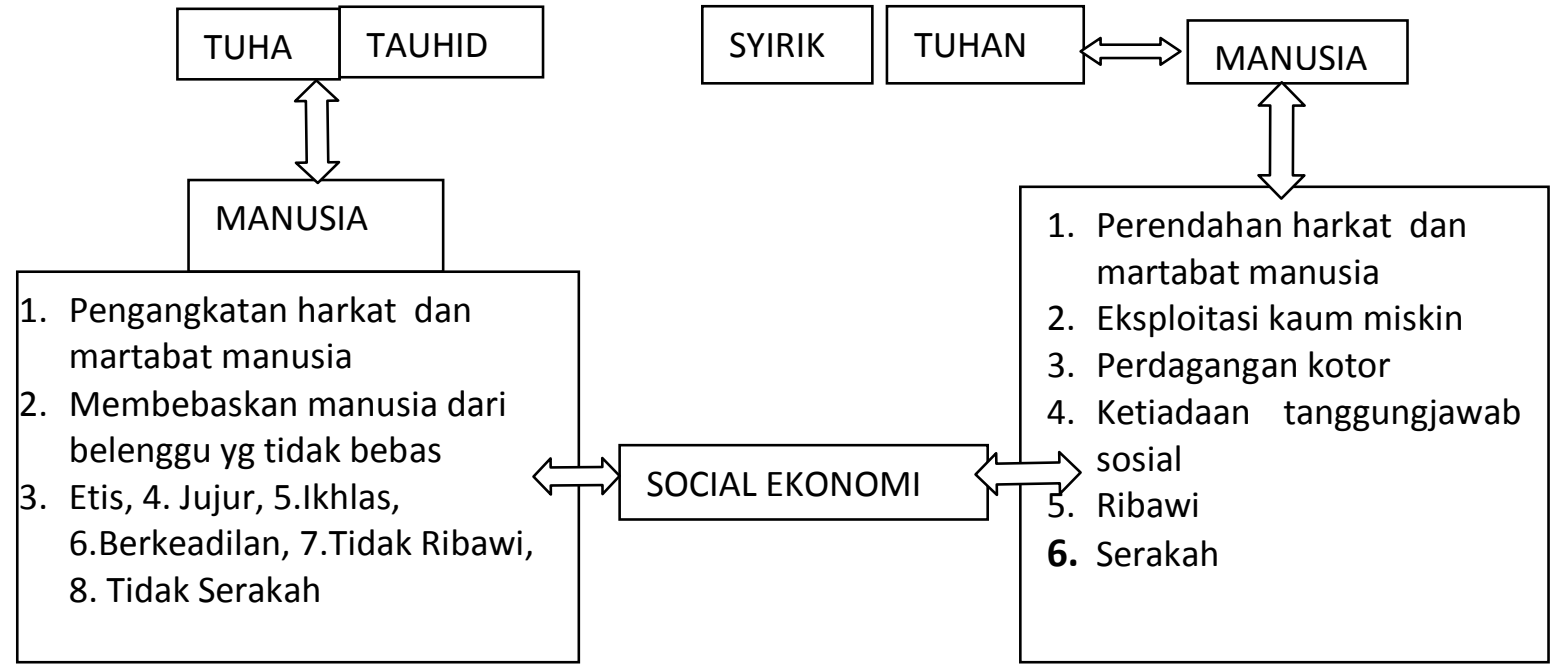

Sumber :Abd Aziz, Etika Bisnis Perspektif Islam

Oleh karena itu, kehidupan nelayan seharusnya melihat prinsip sosial ekonomi di atas. Bahwa kehidupan masyarakat nelayan terutama sosial ekonomi harus memperhatikan ajaran-ajaran

${ }^{29}$ QS Al-Hujurat; 13

30 Ibid,

65 Profit : Jurnal Kajian Ekonomi dan Perbankan 
yang telah tertuang dalam syariat dengan melaksanakan yang diperintah serta menjauhi prilaku yang 5 diatas (eksloitasi, perendahan martabat, dll).

Kedua ; Dalam islam bekerja merupakan ibadah, baik berprofesi sebagai nelayan, buruh, karyawan bahkan seorang manajer/pimpinan. Islam mengapresiasi orang kaya yang yang memperoleh hartanya dengan cara bekerja sesuai dengan yang ajaran syariat, sebagai jalan untuk memakmurkan bumi, begitu juga sebaliknya islam mencela dan mengancam orang yang hanya bekerja untuk menumpuk harta akan tetapi tidak peduli dengan nasib sesama lainnya. (Al Quran 104:1-9). Islam memerintah bekerja dengen cara mengerahkan semua pikiran merupakan sebuah usaha yang dilakukan dengan serius untuk memperlihatkan sebagai hamba Allah yang harus diperintahkan untuk memakmurkan bumi dan memposisikan dirinya sebagai bagian masyarakat paling baik dari segi rupa dan berakhlak dari makhluk lain. Hanya manusia yang bekerja dengan menggunakan pola pikir (akal, ilmu) untuk memenuhi kebutuhan fisik, psikologis dan social akan berhasil dalam kehidupannya serta memperoleh kepuasan lahir maupun batin. ${ }^{31}$ Ada beberapa prinsip bagi pekerja (bekerja) dalam Islam ;3 1) .Kewajiban Mencari Rezeki Halal. Dalam hadits disebutkan : "Bekerja mencari yang halal itu suatu kewajiban sesudah kewajiban beribadah". (HR. Thabrani dan Baihaqi.). Dalam hadits disebutkan apabila tak mau bekerja halal ancamannya adalah neraka. Hadits Sahih mengatakan: "Orang yang paling rugi di hari kiamat kelak adalah orang yang mencari harta secara tidak halal, sehingga menyebabkan ia masuk neraka". (HR. Bukhari).2).Bekerja sebagai ibadah. 3) Bekerja adalah amanah bertujuan untuk memakmurkan bumi.4) Orientasi bekerja sebagai investasi amal saleh untuk kebahagiaan hidup di dunia dan akherat. 5) Bekerja pada bidang-bidang yang baik serta menghindari segala yang diharamkan (keji), tidak isrof (berlebih-lebihan), dsb. 6) Menjauhi pekerjaan yang mengandung unsur seperti fraud (kecurangan) MAGHRIB (Maysir, Ghoror, Riba dan Batil).7)Proses recruitmen mengangkat pekerjaan kepada yang ahlinya (cakap). 8) Memberikan hak-hak pekerja (upah, tanggung jawab) sesuai dengan ketentuan.9) Membayar zakat, pajak, dan lain-lain karena zakat adalah Perintah dari Allah. 10) Bekerja sesuai kemampuan. Dan lain sebagainya.

Ketiga ; dalam perdagangan, bisnis, maupun investasi/bisnis sebagai salah satu bentuk aktivitas seorang muslim dalam mengarungi kehidupan di dunia perlu menghayati etos dalam bekerja dengan sikap dan tingkah laku berlandaskan ibadah dan prestasi yang baik. Oleh karena itu dalam Islam memberikan solusi dengan mengikuti beberapa etos bekerja dalam Islam seperti di bawah ini ; jujur, istiqamah, adil, Menghargai waktu, komitmen dengan akad, aqidah dan i'tikad,

${ }^{31}$ QS ; Taubah; 105, Alhajj; 27, Jumuah, 9-10.lihat juga.. Kajian Tematik al-Qur'an tentang Kemasyarakatan, Suwito, Kerja dalam Perspektif al-Qur'an, 22.

${ }^{32}$ Ismail Nawawi, Isu Nalar Ekonomi Islam II, 2013, Dwiputra Pustaka Jaya, Sidoarjo, 843,

66 Profit : Jurnal Kajian Ekonomi dan Perbankan 
memperluas silaturrahmi, memiliki harga diri, Amanah, bertanggung jawab, hidup hemat dan efisien, dan lain-lain

Dalam al-Quran tentang kegiatan manusia pada bidang-bidang, baik kedudukan sebagai nelayan, bisnisman, wirausaha maupun lainnya, dapat diidentifikasikan pada beberapa konteks: $:^{33}$

a. Status manusia sebagai hamba Allah dengan kewajiban beribadah kepada Allah (QS Hud: 61) serta sebagai Khalifah di bumi dengan kewajiban untuk saling menolong dan bekerja sama (QS. Al Anam:165; QS At Taubah: 71, Al Maidah:32)

b. Kewajiban setiap manusia untuk bekerja dalam mencukupi kebutuhan hidup dan mengaktualisasikan kemampuannya (QS At Taubah: 105, Yunus: 61, 67).

c. Kewajiban manusia mengelola dan memanfaatkan sumber daya alam yang telah disediakan Allah swt (QS. Al Baqarah: 29, Al A'raf: 10), Surat Ibrohim ayat 32-34

Dari beberapa ayat tersebut jelas bahwa manusia sebagai khalifah di bumi mempunyai kewajiban yang harus dilakukan dalam memenuhi kebutuhan hidupnya seperti bekerja sebagai wirausaha, nelayan maupun ia sebagai produsen dalam hal ini adalah mengelola alam/bumi sesuai dengan yang telah digariskan oleh al-Qur'an sendiri. Oleh kerena itu Islam memberikan garis-garis/prinsip-prinsip yang harus dipatuhi sebagai manusia dalam kegiatan dilaut sebagai nelayan maupun sebagai produsen. Prinsip-prinsip tersebut diantaranya; ${ }^{34}$

1. Orientasi visi dan misi harus sesuai dengan syariat, amar makruf nahi munkar, asas tauhid, kebenaran, keadilan dan amanah.

2. Pada tata kelola manajemen, seorang pemimpin seharusnya memberi hak konsumen dari sisi keamanan dan kesehatan, informasi lengkap tentang perusahaan, tidak mencampur hal yang halal dan haram, membayar kewajiban seperti zakat, infaq dan shodaqoh, memperhatikan karyawan, dan lain-lain.

3. Pada tata pemasaran atau marketing seperti pengiklanan, promosi harus jujur, menjauhi penipuan, pemalsuan informasi, dan lain-lain.

4. Pada penetapan harga sesuai dengan ekspektasi laba, tidak mengambil untuk secara berlebihan, tidak tamak, rakus, dan lain-lain sebagainya.

\section{A. PENUTUP}

\footnotetext{
${ }^{33}$ Veitsal Rivai \& Andi Buchari, Islamic Economy, Bumi Aksara, Jakarta, 2009, 100

${ }^{34} \mathrm{Ibid}, 100$
} 
Upaya yang dilakukan masyarakat nelayan untuk keluar dari kondisi ketidakberdayaan dan kemiskinan itu sangat terkait dengan karakteristik lingkungan sumberdaya yang melingkupi mereka, dan relasi- relasi sosial ekonomi sebagai bentuk respon menghadapi kondisi ketidakpastian, keterbelakangan, atau kemiskinan. Karakteristik masyarakat nelayan yang melekat itu berkaitan pula dengan lingkungan sumberdaya yang menjadi tumpuan sumber penghidupan. Karakteristik lingkungan sumberdaya itu menjadikan masyarakat nelayan memiliki karakteristik yang membedakannya dengan karakteristik masyarakat lainnya.

Sementara untuk memperbaiki pendapatan nelayan yang masih berstatus sebagai masyarakat midlee class nelayan, yang selama ini cenderung sangat timpang dibandingkan pendapatan nelayan pemilik, maka diperlukan aturan yang mengatur sistem bagi hasil. Dalam aturan itu ditentukan bagian minimal yang harus diterima setiap buruh nelayan, dibandingkan yang diterima oleh juragan, misalnya setengahnya, atau sepertiganya. Disamping itu juga perlu adanya aturan- aturan yang bisa melindungi kepentingan nelayan lokal. Untuk efektifnya pelaksanaan aturan maka pemerintah juga perlu melibatkan nelayan lokal untuk mengelola wilayah laut sesuai dengan aturan yang ada.

Islam memandang bahwa, usaha yang dilakukan oleh manuisa sepanjang tidak menyalahi aturan, syariat, kode etik maka usaha tersebut akan sustainable, begitu juga sebaliknya. 


\section{Daftar Pustaka}

Freddy, Rangkuti, Teknik Membuat Perancangan Bisnis Dan Analisis Kasus (Jakarta: Gramedia Pustaka, 2000)

Hastarini Dwi Atmanti, 'Kajian Teori Pemikiran Ekonomi Mazhab Klasik Dan Relevansinya Pada Perekonomian Indonesia', 2 (2017), 512

J Mudiyatmoko, Sosiologi Dan Mengkaji Masyarakat (Bandung: Grafindo Media Pratama, 2007)

Khasinah, Siti, 'Hakikat Manusia Menurut Pandangan Islam Dan Barat', Didaktika, 13 (2013), 296317

Kusnadi, M., Konflik Sosial Nelayan Kemiskinan Dan Perebutan Sumber Daya Perikanan (Yogyakarta: LKis Pelangi Aksara, 2002) <https://doi.org/10.22202/mamangan.1313>

Puji Lestari, Ayu, Hukum Laut Internasional Dan Pengaturannya Di Indonesia (Rafika Aditama, 2014)

Satria, A., Pengantar Sosiologi Masyarakat Pesisir (Jakarta: Yayasan Pustaka Obor Indonesia, 2015)

Sharraden, Michael, Aset Untuk Orang Miskin : Perspektif Baru Usaba Pengentasan Kemiskinan (Jakarta: RajaGrafindo Persada, 2006)

Suib, Mohammad Syaiful, 'SINERGITAS PERAN PONDOK PESANTREN DALAM PENINGKATKAN INDEK PEMBANGUNAN MANUSIA (IPM) DI INDONESIA', Islam Nusantara, 1 (2017)

Tahawila, Amrin, 'Studi Akar Kemiskinan Nelayan Di Kelurahan Baiya Kecamatan Tawaeli Kota Palu', Katalogis, 2 (2014), 101-10

Wahyono, Ary, Dkk, Pemberdayaan Masyarakat Nelayan (Yogyakarta: Media Presindo, 2001)

Muhamad Karim dosen Agribisnis Universitas Trilogi, Direktur Pusat Kajian Pembangunan Kelautan dan Peradaban Maritim. https://news.detik.com/kolom/d-3977683/nelayanbutuh-kehadiran-negara).

Masyhuri, "Dimensi Ekonomi Kehidupan Sosial Masyarakat Nelayan", Jurnal Ekonomi dan Pembangunan. 2001, Vol. IX. No. 1

Tommy Kurnia, Ironis, Indonesia Negara Maritim dan Tanab Subur Tapi Nelayan \& Petaninya Miskin, https://www.merdeka.com/uang/ironis-indonesia-negara-maritim-dan-tanah-subur-

69 Profit : Jurnal Kajian Ekonomi dan Perbankan 


\section{tapi-nelayan-petaninya-miskin.html}

Fitri Nurlita, Buchori Asyik, Irma Lusi Nugraheni, Analisis Pendapatan Rumah Tangga Nelayan Burub Di Kelurahan Kangkung Tabun 2016, Jurnal FKIP Universitas Lampung, 17 Agustus 2017

Pasal 33 UUD 1945

Bambang Argo Wibowo, Herry Boesono, Aryo Bayu Aditomo, ANALISIS KEBIJAKAN TERHADAP AKTIVTTAS PENANGKAPAN IKAN NELAYAN KARIMUNJAWA KABUPATEN JEPARA Policy Analysis Towards Karimunjawa Fisherman Catching Activity RegencyJepara, Jurnal Saintek Perikanan Vol. 8. No. 1, 2012

QS : Al-Hujurat; 13

QS ; Taubah; 105,

QS ; Alhajj; 27

QS: Jumuah, 9-10

Kajian Tematik al-Qur'an tentang Kemasyarakatan, Suwito, Kerja dalam Perspektif al-Qur'an, .

Ismail Nawawi, Isu Nalar Ekonomi Islam II, 2013, Dwiputra Pustaka Jaya, Sidoarjo

Veitsal Rivai \& Andi Buchari, Islamic Economy, 2009, Bumi Aksara, Jakarta 